\title{
CRIME PATTERN AND DISTRIBUTION IN REGIONAL ENVIRONMENT: A CASE OF CRIME HOT-SPOT AREAS OF OSUN STATE, SOUTHWESTERN NIGERIA
}

\author{
Yusuf Alapata AHMED* \\ University of Ilorin, Faculty of Social Sciences, Department of Geography and Environmental Management, \\ Nigeria, e-mail: yusufahmed579@gmail.com \\ Citation: Ahmed, Y. A. (2020). Crime Pattern and Distribution in Regional Environment: A \\ Case of Crime Hot-Spot Areas of Osun State, Southwestern Nigeria. Analele Universităţii din \\ Oradea, Seria Geografie, 30(1), 32-40. https://doi.org/10.30892/auog.301104-828
}

\begin{abstract}
This work assessed the pattern and distribution of criminal activities in Osun State Nigeria. It selected ten famous black-spots crime-area in the State using structured questionnaires and secondary data for household-heads and security outfits to obtain relevant data. Factor analysis and multiple regression techniques were employed to analyse data obtained.The findings indicated that most urban residents exhibited a significant higher-level of uncertainties but still want to remain in their ancestral-homes. Suggestions were put forward to governments and security agencies to play priority roles in securing people in their residential areas to conform to other cities of the world.
\end{abstract}

Key words: crime distribution, black-spots, pattern, ancestral-homes, government, Osun State

$$
* \quad * \quad * \quad * \quad * \quad *
$$

\section{INTRODUCTION}

Lots of studies have been carried out on crime incidence in urban environment around the world. In Africa in particular, the studies by Osaghae (1994), Ahmed (2010) provide a tactically and articulate background to such studies in the urban environment where hitherto studies of that nature have been rather sparsely available (Osaghae, 1994; Aguda, 2001). Expectedly in Nigeria, studies on urban crime have been recent and sparse. Some of the few studies include Albert (1995) on Kano, Adisa (1994) on Lagos, Aguda (1994) on Ile-Ife and Ahmed (2010) on Southwestern Nigeria among others. All these studies reveal that crime and violence at the regional areas is expected to continuing to rise because, as urban environment continue to grow into regional areas, so does the social malaise pervade. The growth in urban crime rate in Nigeria is one of the major social problems facing the country in recent time. The dominance of crime in developing countries increases the volatility of the issue, for it pyramids one uncertainty upon others. The concentration of violent crimes in major urban centers worldwide is therefore heralded as an indicator of the breakdown of urban systems. In many urban environment in developing countries today, criminal activities and violence are assuming dangerous tendencies as they threaten lives and property, the 
national sense of well-being and coherence, peace, social order and security; thus, reduces the citizens' quality of life (Aderamo, 2000; Agbola, 2000; Ahmed, 2010). The fear of armed robbery, kidnapping and unlawful arms' possession and militia menace keep Nigerians sleepless at night and they tend to live one day at a time with the fear of whether they may not see the light of any other day, make them assess life as being valueless. Nigerians find it difficult to put their trust on police protection because Nigeria is under policed with an average of one policeman to 5000 Nigerians, compared to that of one policeman to 400 persons in the developed world. Nigerian police are, at times, in collusion with the men of the underworld to unleash terror on their fellow countrymen (Agbola, 1997; Ahmed, 2010).

The Nigeria regional environment consists of diverse groups who arrived at their locations at different times. In most cases, different groups settled at contiguous but distinct locations and in the process of expansion, the earlier settlements grow to absorb each other. Usually in Yoruba land of Southwestern Nigeria, the first settlers constitute the traditional families and land owners (Aguda, 2001). The result is that in many urban environments in the region, new groups are not usually given automatic recognition and they remain the weaker elements for a long time. Also in the world over, discrete communities are known to exist within the cities making urban community cleavages that have become a significant part of the political relationship of the different units. The main interest of this writer is that, issues which relate to these cleavages and segregation have location components and need proper investigation. Trident Press International 2003 - defines crime as any grave offense against morality or social order iniquity. While, crime according to Dambazau (1994) is something which offends the morality of society, or that violates the divine law. The consensus approach to defining crime thus presents it as; offence that is committed by omission, commission or deliberately.

The main focus of this study is centered on socio-economic and political movements that transformed Nigeria between 1985 and 2000. The country had witnessed series of crime waves that transposed a new dispensation into the so-called 'modern democratic government.' Hence, Nigeria witnessed different modes of governance from military to civilian regimes before these periods. The military, in the first instance, solely took advantage of its professional training by using violence to usurp power through coups and counter coups. The politicians in their turn, and in their bids to absorb power, used hired-thugs, or paid assassins/hired killers to perpetrate violence and instill fears on their opponents. The frustrated masses took to formulation of militant groups as witnessed in the uproar of the youths from South-South and establishment of insurgency - Boko-haram/Herdsmen sects from the North-Eastern path of the country who totally disregarded the law. In view of the above, there is therefore, the need to look critically at the pattern and distribution of crime ascendant in the country (Ahmed, 2010). There are also problems of corruption in all ramifications and within all sectors of economy in the private or government sectors in the country. All these encourage many people to take solace in crime, because almost all systems are tending towards not functioning properly or not functioning at all.

There were series of measures taken by government and its agencies such as; the Resource Endowment and Economics of Crime (REEC), the Economic and Financial Crime Commission (EFCC); the National Drug Law Enforcement Agency (NDLEA); the Independent Corrupt Practices and other Related Offences Commission (ICPC) among others, in order to curtail various problems emanating from the national adversities. Therefore, the main objectives of this work are focused on the variations in the pattern and distribution of urban crime and, assessment of factors responsible for the prevalence of different crimes in Osun State Nigeria.

In the light of the foregoing, some questions are raised and should be clarified to articulate the problem and objectives of this study: What pattern formed and distribution tendency shown by crimes committed in Osun state Nigeria in the years under investigation? To what extent are the police and security agents are able to contain crimes perpetrated in the study area and what are the societal/institutional failures that have significantly contributed to the upsurge in the rate of criminal engagements in selected urban environment of Osun State among others? 


\section{THE STUDY AREA}

Osun state was created on August 27, 1991 along with others states in the federation. The state consisted of Osun, Ife, and Ijesa provinces. The state on its creation was made up of 23 LGA's inherited from old Oyo state. Osun State is situated within the tropics and most of the areas fall within wet and dry seasons. The rainy season occurs between April and October, while the dry season, lasts for about November to March annually. Further to this, the rainfall pattern starting from Lagos area and Ijebu-Ode which shows a tendency towards a double maximal separated by a short dry season. There is marked uniformity in the thermal regime in Osun State Southwestern Nigeria. The mean annual temperature exhibits a temperature that increases by $1^{\circ}$ from $27^{\circ} \mathrm{C}$ in the interior of southwestern area. All these attributes emphasized not only the population distribution but also socio-economic development of study area.

Alluvial, ferrisols/ferralitic and ferruginous are the main soil types in Osun State. Accordingly, most soils in Osun State contained very limited reserves of weather able minerals due to intensive leaching. Where soils are good there are concentration of population who use the soil for intensive agricultural practice in the study area. However, among Yoruba of southwestern Nigeria lands are most prominent and valuable assets but sometimes it may lead to liability and conflicts among kinfolk where they cannot compromise (Adeyemi, 1992).

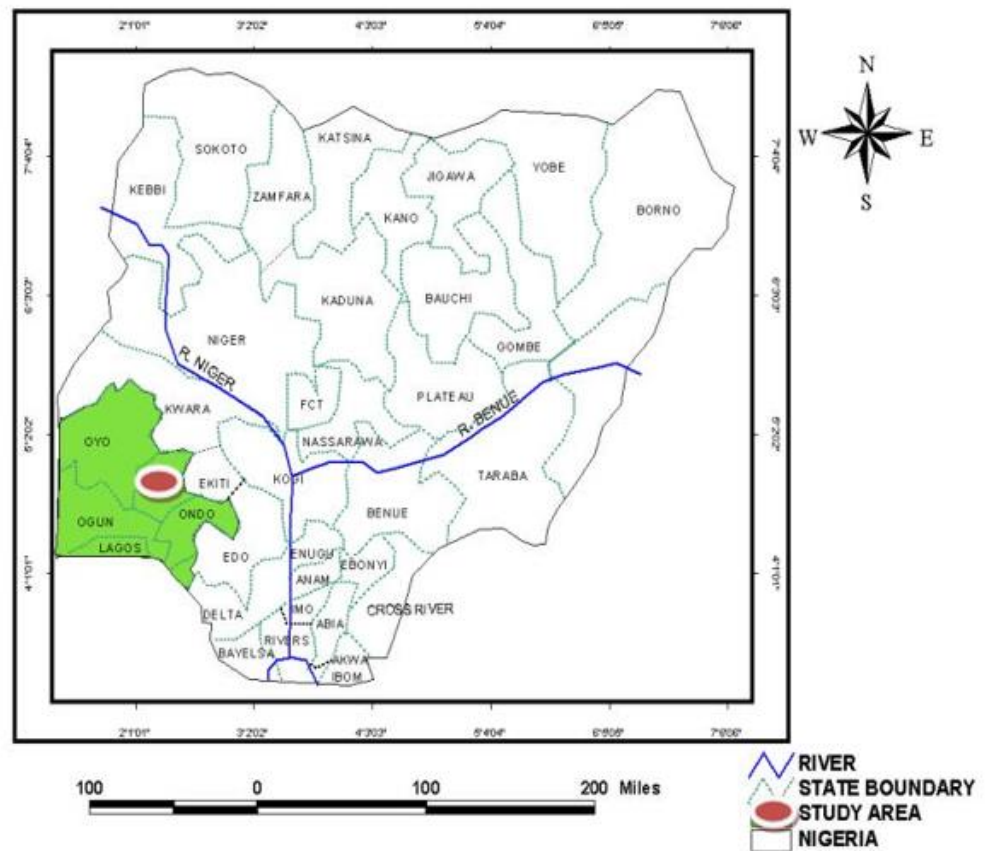

Figure 1. Showing major urban centers in Osun State Source: Author's Fieldwork

\section{METHODOLOGY}

The data used for this study were obtained from both primary and secondary sources majorly acquired from Zone Eleven of the Police Zonal Command Southwestern Nigeria that comprises - Oyo, Osun, Ogun, Ondo and Lagos States. Twenty three set of variable data were generated from this zones and they were categorized into new indicators - Crime against person, Crime against property and Crime against Lawful authority (see tables 1,2). These twenty three variables were later re-written in an attempt to identify the most salient variables to adapt in explaining the main pattern/distribution of crimes in the study area using Factor Analysis statistical method. Olawepo and Ahmed (2003) used a similar method in their work on 'Factorial Ecology of 
a Traditional Urban Centre in Ilorin'. Thus the method is considered as the most suitable for the task of separating factors and identifying development indices for explaining factors affecting distribution of crime in ten selected urban centers in Osun state, Nigeria. Multiple regression analysis was also used to find a way of isolating the most important factor-defining variables sustained from the factor analysis technique (see tables 4, 5, 6). Therefore, this method was adopted to assist in deriving a new model home, and for effective distribution of urban crime wave / patterns in Osun state, Nigeria.

The secondary data-base collected from the police were analyzed using descriptive statistical tool such as; illustrations, tabulation and cross-tabulation of data. This step was used in order to obtain frequency distribution and calculate for each of the variables contained in the questionnaires. It also helped in pulling together the major information for the work. This attempt assists to identify the most salient variables that were adapted in explaining the pattern, and found out the likely causes of crime under investigation. The final step involved the use of Multiple Regression Analysis to explain the factors- determining incidence of crime in the combined selected areas of study. This method was used as a backup, it allows us to assess the relationship that existed between two or more variables while controlling for the effects of others (Nachmias and Nachmias, 1996). The approach also helped in isolating the most important factor-defining variables sustained from the factor analysis technique, and in deriving new model of crime patterns. In other words, the results from the factor scores derived through the use of factor analysis technique served equally as input into multiple regression models (see table 3, 4, 5).

The multiple regression models are defined as:

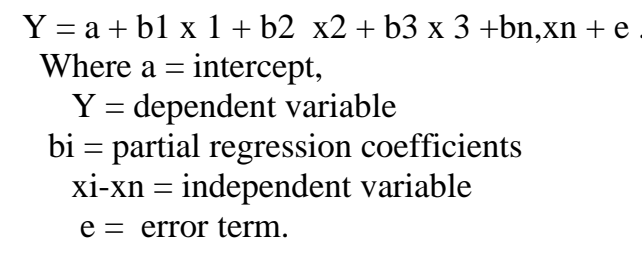

Table 1. Categorization of Offences in Selected Urban Environment Source: Adapted from Olumodeji, (1994) and modified by the Author

\begin{tabular}{|l|l|l|}
\hline \multicolumn{1}{|c|}{$\begin{array}{c}\text { Crime Against } \\
\text { Persons }\end{array}$} & \multicolumn{1}{c|}{$\begin{array}{c}\text { Crime Against } \\
\text { Property }\end{array}$} & \multicolumn{1}{c|}{$\begin{array}{c}\text { Crime Against Lawful Authority } \\
\text { Local Acts. }\end{array}$} \\
\hline Murder & Armed robbery & Cheating \\
\hline Manslaughter & Extortion /with menace & Coining Offence \\
\hline Attempted murder & Theft and stealing & Gambling \\
\hline Suicide and attempted suicide & House breaking & Breach of public peace \\
\hline Grievous harm and wound & Store breaking & \multicolumn{1}{c|}{ Perjury } \\
\hline Assault & False Pretence & Bribery and corruption \\
\hline Child stealing & Forgery & Escape from lawfulcustody \\
\hline Child labour / slavery & Receiving stolen property & Traffic offence \\
\hline Rape and indecent assault & Unlawful possession of property & Liquor Offence \\
\hline Kidnapping & Arson & Fire-arm offence \\
\hline Aberrant offence & Computer Scams & Narcotic offence \\
\hline Others & Others & Others \\
\hline
\end{tabular}


Table 2. Incidences of Crime Rate in Southwestern Nigeria

Source: The Nigeria Police Force Abstracts of Crime and Offences' Statistical Reports

\begin{tabular}{|l|l|l|l|l|l|}
\hline Year & $\begin{array}{l}\text { Offence Against } \\
\text { Persons }\end{array}$ & $\begin{array}{l}\text { Offence Against } \\
\text { Property }\end{array}$ & $\begin{array}{l}\text { Offence Against } \\
\text { Lawful Authority }\end{array}$ & $\begin{array}{l}\text { Offence Against } \\
\text { Local Acts }\end{array}$ & Total \\
\hline 1985 & $\mathbf{2 4 , 4 0 4}$ & 66,436 & 2,667 & 989 & 94,506 \\
1986 & $\mathbf{2 9 , 6 7 7}$ & 79,606 & 2,944 & 1,076 & 113,303 \\
1987 & $\mathbf{3 3 , 8 2 1}$ & 49,117 & 3,660 & 2,181 & 88,779 \\
1988 & $\mathbf{2 1 , 5 8 0}$ & 57,003 & 6,787 & 1,949 & 87,319 \\
1989 & $\mathbf{1 9 , 1 1 1}$ & 88,580 & 9,332 & 1,199 & 18,222 \\
1990 & $\mathbf{2 9 , 6 4 3}$ & 111,333 & 11,943 & 2,066 & 154,985 \\
1991 & $\mathbf{3 6 , 2 0 1}$ & 130,709 & 13,580 & 3,711 & 184,202 \\
1992 & $\mathbf{9 6 , 7 6 1}$ & 153,986 & 15,185 & 5,682 & 271,614 \\
1993 & $\mathbf{9 3 , 7 7 2}$ & 179,885 & 15,499 & 6,722 & 295,878 \\
1994 & $\mathbf{9 0 , 2 7 8}$ & 138,007 & 13,806 & 4,947 & 247,038 \\
1995 & $\mathbf{8 6 , 7 4 4}$ & 138,486 & 11,790 & 4,896 & 241,916 \\
1996 & $\mathbf{9 2 , 6 6 6}$ & 132,333 & 11,361 & 3,994 & 240,354 \\
1997 & $\mathbf{9 0 , 3 4 7}$ & 206,750 & 11,181 & 2,673 & 310,951 \\
1998 & $\mathbf{9 4 , 9 4 7}$ & 396,404 & 12,099 & 5,001 & 508,451 \\
1999 & $\mathbf{1 0 4 , 6 4 6}$ & 556,388 & 19,885 & 4,577 & 685,496 \\
2000 & $\mathbf{9 6 , 7 3 3}$ & 441,962 & 14,333 & 3,070 & 556,098 \\
\hline Total & $\mathbf{1 , 0 4 1 , 3 3 1}$ & $\mathbf{2 , 9 2 6 , 9 8 5}$ & $\mathbf{1 7 6 , 0 6 2}$ & $\mathbf{4 , 1 9 9 , 1 1 1}$ \\
\hline
\end{tabular}

\section{RESULTS AND DISCUSSIONS}

In order to assess the relationship that exists between the selected variables of crime under investigation, a correlation matrix for each factor executed was put into computerized form. The correlations among the twenty three variables were dispensed accordingly (see table 3, 4, 5). By putting into consideration values that are larger than +0.60 , we can observe that many of the variables are closely related. Though, the pattern of values that are significant are shown in two levels, those correlations that are significant at 0.01 (99\% at 2-tailed) level and at 0.05 (95\% at 1tailed). But the higher significant levels are seen to have common with 0.01 significant levels. For example, there is high correlation at about twelve different levels. Thus: between murder and attempted murder between Grievous wound and assault, rape, theft and stealing, as well as armed robbery. Also between burglary and grievous wound, receiving of stolen goods; assault, theft and grievous. Also between house breaking and theft; breach of public peace and arson, computer scam; as well as between breach of public peace and house breaking.

Table 3. Rotated Component Factors

Source: Author's Computer Output

\begin{tabular}{|c|c|c|c|c|c|}
\hline Offence & $\begin{array}{c}\text { Unemployment } \\
\text { Rate Factor } \\
(\mathbf{I})\end{array}$ & $\begin{array}{c}\text { Rural/Urban } \\
\text { Migration } \\
\text { Syndicate } \\
(\mathbf{I I})\end{array}$ & $\begin{array}{c}\text { Inadequate } \\
\text { No.of Police } \\
\text { Factor } \\
(\text { III) }\end{array}$ & $\begin{array}{c}\text { Family } \\
\text { Obligation } \\
\text { Factor } \\
\text { (IV) }\end{array}$ & $\begin{array}{c}\text { Drug Abuse/ } \\
\text { Trafficking } \\
\text { Factor } \\
\text { (V) }\end{array}$ \\
\hline Murder & .23 & .08 & -.04 & .81 & -.01 \\
Attempted murder & -.07 & -.01 & .14 & .79 & .19 \\
Suicide & -.01 & -.017 & .05 & .15 & .65 \\
Grievous wound & .68 & 18 & -.04 & -17 & .04 \\
Assault & .61 & -.32 & -.30 & -.07 & -18 \\
Child stealing & .27 & .20 & -.02 & -.06 & 58 \\
Rape & .80 & -.08 & .14 & .15 & -.03 \\
Kidnapping & -.08 & .01 & .69 & -.05 & .15 \\
\hline
\end{tabular}




\begin{tabular}{|c|c|c|c|c|c|}
\hline Aberration & -.20 & -.09 & .78 & -.00 &. .15 \\
\hline Armed robbery & .40 & -.05 & -.07 & .45 & -.44 \\
\hline Demand by menace & -.07 & .67 & -.00 & -.19 & .08 \\
\hline Theft/stealing & .80 & -.21 & -.12 & -.09 & .05 \\
\hline Burglary & .80 & .09 & .15 & .17 & .02 \\
\hline House breaking & .79 & -.43 & -.02 & -.07 & -.16 \\
\hline Forgery & .28 & -.18 & .48 & .11 & -.17 \\
\hline Bribery & .05 & .07 & .40 & .08 & .60 \\
\hline Perjury & -.14 & .29 & .59 & .02 & .03 \\
\hline Receiving stolen items & .18 & .48 & -.13 & .34 & -.40 \\
\hline Unlawful arms Possess & .49 & -.23 & .56 & -.05 & .24 \\
\hline Arson & -.03 & .78 & -.15 & .05 & -.09 \\
\hline Preach of peace & .65 & -.58 & -.00 & -.05 & -07 \\
\hline Escape from custody & -.00 & .79 & .37 & .08 & .04 \\
\hline Computer scam & .82 & .16 & -.13 & .13 & -.07 \\
\hline Eigen Value & 5.17 & 2.89 & 2.53 & 1.82 & 1.74 \\
\hline$\%$ of Variance & 22.55 & 12.57 & 11.01 & 7.93 & 1.74 \\
\hline Cumulative \% & 22.55 & 35.12 & 46.13 & 54.06 & 61.62 \\
\hline
\end{tabular}

Table 4. Distribution of the Component Scores on Measures of Crime in Osun State Source: Author's Computer Output

\begin{tabular}{|c|c|c|c|c|c|}
\hline S/No.Variance & ComponentI & ComponentII & ComponentIII & ComponentIV & ComponentV \\
\hline 1. Child Stealing & 0.000 & 0.852 & 0.000 & 0.128 & 0.000 \\
\hline 2. Forgery & 0.000 & 0.844 & 0.210 & 0.000 & 0.000 \\
\hline 3. Perjury & 0.000 & 0.778 & -0.173 & 0.000 & 0.000 \\
\hline 4. Suicide & 0.186 & 0.733 & -0.115 & 0.160 & 0.122 \\
\hline 5. Aberration & 0.186 & 0.641 & -0.197 & 0.253 & 0.111 \\
\hline 6. House Breaking & 0.234 & 0.575 & -0.245 & 0.473 & 0.000 \\
\hline 7. Computer Scams & 0.241 & -0.154 & 0.786 & 0.000 & 0.125 \\
\hline 8 Armed Robbery & 0.118 & 0.000 & 0.622 & 0.000 & 0.538 \\
\hline 9. Assaults & 0.304 & 0.504 & -0.604 & 0.158 & 0.249 \\
\hline 10.Theft/Stealing & 0.300 & 0.544 & -0.599 & 0.233 & 0.000 \\
\hline 11.Burglary & 0.307 & 0.281 & -0.574 & 0.530 & -0.110 \\
\hline 12.Demand by Menace & 0.000 & 0.536 & 0.000 & 0.305 & -0.106 \\
\hline 13.Escape custody & 0.000 & 0.115 & 0.000 & 0.873 & 0.000 \\
\hline 14. Arson & 0.140 & 0.177 & -0.110 & 0.869 & 0.105 \\
\hline 15.Bribery & 0.340 & -0.154 & 0.601 & 0.164 & 0.000 \\
\hline 16.Receiving Stolen goods & 0.141 & 0.437 & 0.214 & 0.501 & -0.214 \\
\hline 17. Unlawful arms possession & 0.181 & 0.253 & -0.422 & 0.370 & 0.000 \\
\hline 18.Attempted murder & 0.000 & 0.208 & 0.000 & 0.890 & 0.121 \\
\hline 19. Kidnapping & 0.775 & 0.011 & 0.122 & 0.000 & 0.000 \\
\hline 20. Murder & 0.000 & 0.000 & 0.533 & -0.151 & 0.660 \\
\hline 21. Rape & 0.787 & -0.126 & 0.000 & 0.000 & 0.000 \\
\hline 22. Preach of peace & 0.636 & 0.296 & 0.465 & -0.215 & 0.000 \\
\hline 23. Grievous wound & 0.572 & 0.101 & -0.203 & 0.153 & 0.360 \\
\hline
\end{tabular}

\section{Factors Explanation}

All the variables that are responsible for the causes and effects of crimes commitment in the study area are relatively important. Though, there is variability in the contributions of each of these factors which could be obviously seen as the 'eigen values' are greater than one (see table 3). We can equally say that when interpret the components as representing groups of variables, the considering component loadings is greater than +0.60 and labelled the components accordingly. For our attention, factor I accounts for $22.55 \%$ of the total variance explained with its significant positive loading. This factor is tagged 'Condition of Unemployment Rate'. The characteristics of this factor tend to show that there are more people that take into crimes when they are unable to earn good standard of living that can meet their family needs (see tables 4 and 5). 
Table 5. Matrix of Inter-Correlation on Crime Measures in Osun State Source: Author's Fieldwork

\begin{tabular}{|c|c|c|c|c|c|c|c|c|c|c|c|c|c|c|c|c|c|c|c|c|c|c|c|}
\hline minor & .000 & & & & & & & & & & & & & & & & & & & & & & \\
\hline Atteptand & $395^{\circ}$ & 1.000 & & & & & & & & & & & & & & & & & & & & & \\
\hline Sinicide & .0180 & .122 & 1.000 & & & & & & & & & & & & & & & & & & & & \\
\hline Girvomom & $296^{\circ}$ & $0.8 \mathrm{~s}$ & 0.000 & 1.000 & & & & & & & & & & & & & & & & & & & \\
\hline \begin{tabular}{|l|l} 
Assault \\
\end{tabular} & .073 & -0.33 & .120 & $494^{\circ}$ & 1.000 & & & & & & & & & & & & & & & & & & \\
\hline (mildsolen & -0.031 & .006 & .044 & 205 & .030 & 1.000 & & & & & & & & & & & & & & & & & \\
\hline Rape & $2000^{*}$ & .115 & क्वा & $.403^{*}$ & 304 & .101 & 1.000 & & & & & & & & & & & & & & & & \\
\hline Kidrappin & .052 & .028 & .095 & -0.035 & .230 & .061 & .048 & 1.000 & & & & & & & & & & & & & & & \\
\hline Abemation & .039 & .129 & $201{ }^{+4}$ & .III & .113 & $230^{\circ}$ & 4960 & $2811^{*}$ & 1.000 & & & & & & & & & & & & & & \\
\hline Ammkobse & $4366^{\circ}$ & .162 & $-215^{\circ}$ & $224^{4+}$ & $316^{\circ 4}$ & -.040 & 3.34+" & -.058 & $281^{2}$ & 1.000 & & & & & & & & & & & & & \\
\hline INd Menace & -.009 & - coss & -.101 & .115 & $-316^{\circ}$ & $\cos x$ & -.031 & .096 & -000 & -10 & 1.000 & & & & & & & & & & & & \\
\hline Theflisale & .113 & $-0 \pi 1$ & .000 & $\left.44\right|^{1+}$ & $543^{2+}$ & .1060 & $.0011^{1+}$ & .143 & -203 & 201 & \begin{tabular}{|c|}
.181 \\
\end{tabular} & 1.000 & & & & & & & & & & & \\
\hline Barylury & $3 \times 2^{24}$ & 0.025 & .006 & $5\left(0, x^{2}+\right.$ & (3) & .167 & $.6022^{2+}$ & .075 & -.044 & 335 & .001 & $400^{\circ}$ & 1.000 & & & & & & & & & & \\
\hline Howstreal & .183 & .017 & .149 & $409^{+1}$ & $531^{\mathrm{F}^{2}}$ & .189 & $6.632^{+1}$ & -.056 & .136 & 249 & -3000 & $.7760^{\circ}$ & Sख़ी & 1.000 & & & & & & & & & \\
\hline Furgery & 0.051 & .164 & 0.034 & .114 &  & .001 & 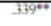 & (59) & .109 & Cos9 & -.0006 & $232^{2}$ & $212^{2}$ & $230^{\circ}$ & 1.000 & & & & & & & & \\
\hline \begin{tabular}{|l|l} 
Briniery \\
\end{tabular} & -.024 & .163 & $228 x^{\prime \prime}$ & .033 & -1.32 & .151 & 0.053 & $3,3]^{2}$ & $278^{\circ}$ & .23 & \begin{tabular}{|l|}
.009 \\
\end{tabular} & -.044 & .098 & \begin{tabular}{|l|}
.063 \\
\end{tabular} & .091 & 1.000 & & & & & & & \\
\hline$P_{t e j u r y}$ & -.044 & .061 & 0060 & -.014 & $.2 \times 50^{\circ}$ & .023 & -.120 & .133 & (3) & $-\pi$ & \begin{tabular}{|l|}
.009 \\
\end{tabular} & .194 & -0.29 & -2000 & .115 & $231^{\circ}$ & 1.000 & & & & & & \\
\hline R sisoletiond & $306^{\circ}$ & .053 & $-200^{\circ}$ & $2061^{1+*}$ & .021 & $-(599$ & $.194^{\circ}$ & $-2 M^{2}$ & -167 & $2 \times 5$ & \begin{tabular}{|l|}
.183 \\
\end{tabular} & .015 & $2011^{\circ}$ & -.123 & .039 & .1733 & .017 & 1.000 & & & & & \\
\hline Preptace & 0.099 & .129 & $2011^{\prime \prime \prime}$ & .111 & .113 & $230^{\circ+4}$ & 496 & $281^{1+\pi}$ & $2 y^{4}$ & .127 & $-.1 \times 3$ & $361^{10}$ & $40^{2+}$ & $504^{4}$ & $305^{+4}$ & $2 x^{2}$ & .184 & $.250^{\circ+4}$ & 1.000 & & & & \\
\hline Arsom & cass & .006 & .100 & .019 & $.200 \%$ & .139 & .006 & $.13 \mathrm{~s}$ & .139 & $\frac{.0 \times 3}{10 \times 3}$ & उत्रा" & -.135 & -0.039 & $-349^{\circ}$ & .172 & .140 & $2 \times 11^{2+}$ & $245^{\circ}$ & $.240^{\circ}$ & 1.000 & & & \\
\hline Unturmpoes & .098 & .024 & .102 & $34)^{2+1}$ & डब & 0.00 & $530^{\circ+2}$ & -.096 & .180 & 201 & -378 & ${ }^{.624^{4}}$ & $442^{2+}$ & $.349^{+2}$ & $200^{\circ}$ & .032 & $-300^{*}$ & $-218^{\circ}$ & 300 & $-403^{\circ}$ & 1.000 & & \\
\hline Espromenon & .015 & .098 & .007 & .140 & $-300^{\circ}$ & 0.022 & .001 & $234^{+7}$ & $2000^{\circ}$ & .000 & $.423^{\circ}$ & -139 & .040 & $.340^{\circ}$ & 0.030 & $234^{\circ}$ & $400^{\circ}$ & $299^{\circ}$ & .019 & .499" & $-450^{\circ}$ & 1.00 & \\
\hline Compsam & $2 \times 0^{\circ-1}$ & .063 & .012 & $6280^{\circ+1}$ & $459^{2+2}$ & .098 & $.5005^{\circ+1}$ & .141 & .273 & 307 & -.056 & 5.49 & .6.39" & $5311^{2}$ & .142 & $.0 \times 1$ & .152 & $2060^{0+}$ & $28 x^{2+}$ & 0.014 & उख़े & 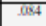 & 1000 \\
\hline
\end{tabular}

* Correlation is significant at the 0.05 level (2-tailed

* Correlation is significant at the 0.01 level (2-tailed)

Factor II exhibited a high positive loadings and accounts for $12.57 \%$ of the total variance. The factor is termed 'Rural/Urban Migration Syndicate'. Due to the belief that there are more employment opportunities in major urban centers, many able bodied youths drift to the urban centers/cities like Osogbo, Ife, Odo-otin and other areas in Osun State Nigeria. Factor III on the other hand, explained $11.01 \%$ of the total variance that has significant positive loadings on different crimes committed and reported. Most of the crimes committed could have been curtailed if there are adequate security personnel in the selected areas of Osun State; hence this factor is referred to as 'Police Inadequacy Factor.' More importantly, Factor IV accounted for $7.93 \%$ of the total variance explained. This factor has to do with notable crimes affecting individual personality(Crime Against Persons). Thus is labeled 'Family Responsibility/Obligation Factor'. Most of the obligations are not met due to meager income of the household heads.

Lastly, Factor V accounted for $1.74 \%$ of the total variance and is basically an aggregate measure of positions which some people uphold in the community. For instance, some individuals aid or abet crime like; drug abuse and trafficking. Thus, this factor is termed 'Drug Abuse/Trafficking Factor'. Factor V is also significant because it influences other variable factors to work. Criminals use drugs as aid in order to commit crimes. This factor accounts for $1.74 \%$ of the total variance.

\section{INCIDENCE OF NEW CRIME MODEL AND PLANNING IMPLICATIONS}

Modeling of crime incidence is imperative simply because it assists in explaining vividly all sorts of crime problems in Osun State and Nigeria as a whole. Thus, as a new model was developed, it further aids the prediction of crime perpetration in as to render good planning by the governments of all categories for the citizens in the country at present and in the near future for a better crime management. Therefore, the pattern/distribution of crime incidence in Osun State was not by accident but by finding. In addition to the above, Multiple Regression Analysis (see table 6) was put forward in order to find a way of isolating the most salient factor defining variables 
sustained from the factor analysis technique as discussed early. This model is interpreted as; selected five variables which is accessibility to condition as: Unemployment rate, Rural-urban migration, Police inadequacy, Family obligation and Drug abuse/trafficking as tabulated above. The planning implications therein indicated what real happens all over the world most especially among the developing countries. Implications such as; crimes perpetration, their spatial pattern and distribution, and above all its consequences on individuals, communities, governments and other stakeholders are its focus.

Table 6. Multple Regression Between Total Crime and Factor Defining Variables Source: Author's Computer Output

\begin{tabular}{|c|c|c|c|c|c|c|}
\hline $\begin{array}{c}\text { List of Variables and } \\
\text { Intercepted }\end{array}$ & $\begin{array}{l}\text { Regression } \\
\text { Coefficient }\end{array}$ & $\begin{array}{c}\text { Standard } \\
\text { Error }\end{array}$ & $\mathbf{R}$ & $\mathbf{R}^{2}$ & $\begin{array}{c}\text { Total } \\
\text { Contribution } \\
(\%)\end{array}$ & $\begin{array}{l}\text { T-Test } \\
\text { Value }\end{array}$ \\
\hline Intercept & 2464177 & 3.1122 & - & - & 22.09 & 0.001 \\
\hline X1.Unemployment Rate & 375363 & 0.6911 & 0.47 & 0.2209 & 22.09 & 0.001 \\
\hline X2. Rural-Urban Migration & 47526.23 & .03455 & 0.55 & 0.3025 & 30.25 & 0.01 \\
\hline X3. Inadequate No. of Police & 42487.5 & .03026 & 0.35 & 0.1225 & 35.00 & 0.566 \\
\hline X4. Family Income/Obligation & 4527.9 & .03110 & 0.44 & 0.1936 & 19.36 & 0.233 \\
\hline X5. Drug Trafficking/Abuse & 14695.1 & .03340 & 0.14 & 0.0196 & 1.96 & 0.001 \\
\hline
\end{tabular}

Another implication is that geographers, urban planners and political leaders can make use of the model as reference point in their bid for proper programme execution for the citizens.

Multiple Regression Model.

Equation I (Predictive Model)

$\mathrm{Y}=3691344.4-289265$ CONUMRATE +457743.9 RURMIGRATE -214200.5 POLINADQUACY + 243433.5 FAMOBLIGATION - 59518.3

DRUGTRAFFICK. (eq. 1)

$\left(\mathrm{R}^{2}=80.6 \%\right.$ std. error 24.4$)$

\section{CONCLUSION AND RECOMANDATIONS}

This work has eventually served as eye-opener to some hidden facts and planning implications about criminal activities in some local government areas/zones of Osun State, Southwestern Nigeria. The work has demonstrated the effect of social structure on human beings leading to crime incidence in various hot-spots in the state. The reaction of human beings for survival within the social structure has constituted a corpus of knowledge relevant to examination of youths' engagement in urban violence. Youths who are found in criminal activities absorb crime as a method of adjusting to social malignant. To eradicate crimes therefore, fundamental societal survival techniques must be dissociated from crime. This requires a fundamental restructuring of the society towards productive engagement in the sector that can provide the need and positive aspiration of the people in cities all over the world. Positive achievement is obtained through educational institutions, community participation in productive engagements, and above all, where governments perform its tasks appropriately. To reduce youths' perceived negative attitude, societal negatives must be ameliorated.

The incidence of crime wave and its intensity has been on increasing not only in Nigeria but all over the world. Therefore, urgent needs for safety and security through diverse means are overdue in order to make global cities' environment livable. The spread of crime in cities world-wide are becoming a foremost phenomenon and a proper consideration by all stakeholders such as; the government, the security personnel and the communities' participation in crime reduction is duly warranted. 
To make all suggestions work in the areas studied, Nigeria, and in developing world as a whole, therefore, it is recommended that:

- residents of cities need to maintain positive attitude and remain calm at any crime alert condition; they should not feed their minds with much fear from unnecessary apprehension and panic (Ahmed, 2010). They must always remain unruffled, steadfast, and help one another especially when there is a need for help in their neighborhoods.

- people should always mind their own business, but be cautious and vigilant about all that go around them mostly among the people living in cities.

- residents of cities in Nigeria should avoid carrying or displaying some criminogenic items such as; huge sum of money or attractive wares that can invite criminals to their neighborhoods.

- efficient security coping mechanism should be taken up by the government and by the security agents, such that the police patrols is extended to all nooks and corners of the city centers, local government areas, and at the regional settings among others.

- security awareness should be taken seriously on new settlers' settlements, among the communities especially when building new residential quarters. The use of day and night vigilantes or community guards should take a paramount role in the living areas of the cities and neighborhoods. It is when all these suggestions are put in place that cities in Nigeria would attract a more stable society which encourages investment (domestic and international), a more secure community with abundant opportunities for all ethnic groups in the country. Any contrary propositions to the above would not enhance a free flow of commerce and ideas, freedom of speech and the press, as well as new innovation into the country.

\section{REFERENCES}

Aderamo, A.J. (2000). Spatial Pattern of Intra-Urban Trip in Ilorin, Nigeria. In Geo-Studies Forum, International Journal of Environmental and Policy Issues, (1 \& 2): 46-57.

Adeyemi, A.A. (1992). Re-Assessing the Age of Criminal Responsibility in Nigeria. In Women and Child renunder Nigeria Law, Kalu and Osinbanjo (eds.) Lagos.

Adisa, J. (1994). Urban violence in Lagos. Urban Violence in Africa: Pilot Studies. Ibadan, Nigeria: IFRA.

Agbola, T. (1997). The architecture of fear: urban design and construction response to urban violence in Lagos, Nigeria. Ifra.

Agbola, T. (2000). Urban violence, urban in security and the challenge of good urban governance; the evolving disturbing scenario from Abuja, Nigeria. Journal of the Nigerian Institute of Town Planners (JNITP), 1(12), 59-78.

Aguda, A.S. (1994). Area Ecological Analysis of Crime. A Case Study of a Nigerian City. Urban Management and Urban Violence in Africa, 1, 1-8.

Aguda, A.S. (2001). Areal and Ecological Analysis of Crime: A Study of a Nigerian City. Urban Management and Urban Violence in Africa, IFRA. Ibadan.

Ahmed, Y.A. (2010). Trend and pattern of urban crime in southwestern Nigeria. Unpublished Ph. D. Thesis, Department of Geography \& Environmental Management University of Ilorin, Nigeria.

Albert, I.O. (1995). Urban management and urban Violence in Africa.

Dambazau, A.R.B. (1994). Law and Criminality in Nigeria: An analytical discourse. University Press Plc.

Nachmias, C. F., \& Nachmias, D. (1996). Research methods in the social sciences, $5^{\text {th }}$. Edward Arnold, New York.

Olawepo, R.A., \&Ahmed, Y.A. (2003). Factorial Ecology of a Traditional Urban Centre. A Case Study of Ilorin. Centre Point. A Journal of Intellectual, Scientific and Cultural Interest, University of Ilorin, Nigeria.

Osaghae, E.E. (1994). Urban Violence in South Africa. Osaghae, EO, Toure, I, Kouame, N. Albert, I O and Adisa, J. (eds) Urban Violence in Africa, Pilot Studies. Ibadan: IFRA pp1-49.

Submitted:

Octomber 04, 2019
Revised:

January 05, 2020
Accepted and published online February 19, 2020 